Chapter 7

\title{
Functional Implications of MHC Associations in Autoimmune Diseases with Special Reference to Type1 Diabetes, Vitiligo and Hypoparathyroidism
}

\author{
Rajni Rani and Archana Singh \\ Additional information is available at the end of the chapter \\ http://dx.doi.org/10.5772/57494
}

\section{Introduction}

Immune cells get educated in the thymus during development to recognize self antigens so that there are no immune responses against self antigens. However, whenever they encounter non-self antigens like bacteria or viruses, they are recognized as non-self and immune response takes place against them to save us from infections. While the basic purpose of the immune response is to save us from infections, something goes awry in some cases such that the self antigens are recognized as foreign by one's own immune cells which attack the cells /organs containing those antigens presuming them to be foreign. This results in auto-immune disorders like Type 1 diabetes, vitiligo or hypoparathyroidism, the focus for the present chapter. All these disorders are complex, multi-factorial, organ specific disorders where auto-immune responses have been implicated due to presence of auto-antibodies and auto-antigen specific $\mathrm{T}$ cells in the peripheral circulation of the patients. Although what triggers the autoimmune responses in these disorders is not clearly understood, association with certain major histocompatibility complex (MHC) alleles has been considered a hallmark of autoimmune disorders [1] since they have a role in antigen presentation that orchestrates the antigen specific adaptive immune responses.

Major Histocompatibility Complex (MHC) is a set of glycoprotein molecules present on the cell surface of nucleated cells encoded by several polymorphic genes localized on chromosome 6 of man. In human, MHC is known as Human leukocyte Antigens (HLA). MHC region is spread over 3.84 megabases of chromosome 6p21.3 and is the most gene dense region of the human genome with 224 genes. 128 of these 224 genes are known to be expressed. And $40 \%$ of these genes have immune related functions [2]. HLA constitutes a small part of the MHC 
region. Major function of HLA molecules is to present antigenic peptides to T cells. HLA can be broadly classified into two major classes: class-I and class-II. HLA class-I genes are HLAA, $-B$ and $-C$. These are classical class-I genes which are very polymorphic with 2365,3005 and 1848 alleles respectively.

The MHC class-I molecules are present on the surface of all nucleated cells and present antigenic peptides to the $\mathrm{CD} 8^{+}$cytotoxic T cells. MHC class-I molecule is a hetero-dimer of a heavy and a light chain. The molecular weight of the heavy alpha chain is about 40-45 KDa and that of the light chain, beta 2 microglobulin $\left(\beta_{2} \mathrm{~m}\right)$ is $12 \mathrm{KDa}$ [3]. The genes for the alpha chains are encoded on chromosome 6. However, the gene for $\beta_{2} \mathrm{~m}$ is encoded on human chromosome 15. The heavy chain of the MHC class-I molecule has three domains alpha $1(\alpha 1)$, alpha $2(\alpha 2)$ and alpha $3(\alpha 3)$. Alpha $1(\alpha 1)$ and alpha $2(\alpha 2)$ domains are the most polymorphic domains since they constitute the peptide binding groove of the MHC molecule. These polymorphic domains are encoded by exons 2 and 3 of the genes encoding MHC class-I alpha chain which has in total 8 exons. The peptides that are presented by the MHC molecules have allele specific motifs i.e., certain peptides can be presented by certain MHC molecules. The affinity of the peptide to bind to the peptide binding groove is determined by the anchors present on the peptide binding groove where the peptides go and bind through hydrogen bonds. Specific motifs or the amino acid residues present in the pockets of the peptide binding grove which are involved in binding the side chains of complimentary residues of the peptide determine which peptides would bind to which MHC molecule [4, 5]. Pockets B (key residues at positions 9, 45, 63, 67, 70 and 99) and $F$ (key residues at positions 77, 80, 81 and 116) of alpha chain are the main anchors which engage the peptides at their amino acid positions 2 and the C-terminus [6]. However, several alleles of the MHC share peptide binding specificities i.e. similar peptides may be presented by different MHC molecules. These alleles are clustered in supertypes [6].

HLA class-II molecules are expressed on antigen presenting cells like macrophages, dendritic cells, B cells, thymic epithelium and activated T cells [7]. MHC class-II molecules present antigenic peptides to the $\mathrm{CD}^{+} \mathrm{T}$ helper cells (Th cells) which in turn initiate a cascade of immunological events that result in activation of $\mathrm{CD} 8^{+}$cytotoxic $\mathrm{T}$ cells and B lymphocytes [2]. $\mathrm{CD}^{+} \mathrm{T}$ helper cells get activated when a non-self antigen is presented to them. Thelper cells are of two types T helper 1 (Th1) and Th2. Th1 cells secrete cytokines like Interferon gamma and TNF-alpha which are involved in cell-mediated immune responses as they activate the cytotoxic T cells which have already seen the antigen in the context of MHC class-I. Th2 cells, on the other hand, secrete IL-4, IL-5 and/or IL-6 which are involved in humoral immunity as they activate the $B$ cells to become plasma cells which make the antibodies against antigen they have seen. Thus an immune response takes place which varies in strength depending on the host factors and the peptides being presented.

The classical MHC class-II glycoproteins in humans are HLA-DR, -DP and -DQ. The MHC class-II molecule is a heterodimer of two polypeptide chains: an alpha (25-33 KDa) and a beta chain $(24-29 \mathrm{KDa})[8,9]$. Unlike MHC class-I, both alpha and beta chains of the class-II molecule are encoded on chromosome 6. DRB1 gene encodes DR beta chain while DRA1 encodes DR alpha chain with 1355 DRB1 alleles and 7 DRA1 alleles. Similarly DQB1 and DPB1 encode beta 
chains of DQ and DP molecules with 416 and 190 alleles respectively and DQA1 and DPA1 encode the alpha chains of DQ and DP molecules with 51 and 37 alleles respectively [10, 11].

Besides the classical class-I and class-II genes there are several non-classical HLA genes with specialized functions and also pseudo HLA genes present in the MHC region. However, they will not be discussed here since their roles are not very clearly understood in autoimmunity.

A recurring theme of several autoimmune disorders is the aberrant presentation of self antigens to the immune system that triggers downstream perturbations. Under normal circumstances most of the MHC molecules are occupied by self peptides and the T cells are tolerized against them during thymic education so that auto-immune responses do not take place, however, sometimes there is a break in the tolerance resulting in recognition of self as non-self by the immune system which results in an auto-immune response. This break in tolerance could be due to low expression of some antigens in the thymus which may result in self-reactive $\mathrm{T}$ cells to reach the peripheral circulation. Or it could be due to escape of selfreactive T cells from clonal deletion during T cell development. Since associations with MHC alleles have been considered a hallmark of autoimmune disorders due to their role in antigen presentation, we have studied HLA alleles in two common and one rare autoimmune disorders: Type1 diabetes, vitiligo and hypoparathyroidism.

\section{Patients and controls}

DNAs were extracted using standard protocol from $10 \mathrm{ml}$ of blood from type 1 diabetes ( $\mathrm{N}=211)$, vitiligo $(\mathrm{N}=1404)$, hypoparathyroidism patients $(\mathrm{N}=134)$ and 902 normal healthy controls from the same ethnic background after obtaining informed consent. All the patients attending diabetes of young clinic were carefully assessed and categorized as type 1, type 2 and fibrocalculous pancreatopathy as per the recent classification by American Diabetes Association expert committee [12,13]. All of the T1D subjects included in the study required insulin for glycemic control and 51 of them had history of ketosis at presentation. Insulin requiring patients with fibrocalculous pancreatopathy and subjects with diabetes in whom glycemic control was achieved with diet and oral hypoglycemic agent were excluded from the study $[12,14]$.

Vitiligo group consisted of 1404 North Indian patients enrolled at Dr. Ram Manohar Lohia Hospital (RMLH), and All India Institute of Medical Sciences (AIIMS), New Delhi Diagnosis of vitiligo was based on clinical examination done by dermatologists. Clinically, the cases were classified as having Generalized (Vulgaris, Acrofacial, Universalis) or Localized (Focal, Acral, mucosal and segmental) forms of vitiligo. The replication study was done on 355 vitiligo cases from Gujarat, a state in west of India [15].

Idiopathic hypoparathyroidism group consisted of 134 unrelated patients who attended the endocrine clinics of All India Institute of Medical Sciences during 1998-2011. The diagnosis of $\mathrm{IH}$ was based on presence of hypocalcemia, hyperphosphatemia, low serum intact PTH, normal renal function and serum magnesium levels. Patients with post surgical hypopara- 
thyroidism were not included. Patients with clinical features of APECED syndrome indicated by mucocutaneous candidiasis or presence of adrenocortical autoantibody were excluded from the study[16].

Nine hundred and two ethnically matched unaffected controls from North India were used for all three studies and 441 ethnically matched unaffected controls from Gujarat were studied in the replication study for vitiligo only. None of the unaffected controls had personal or family history of T1D, vitiligo, hypoparathyroidism or any other autoimmune or infectious disease.

All Cases and control samples were collected after obtaining informed consent and Institutional Human Ethics Committee's clearance from all the institutes/Hospitals involved, following declaration of Helsinki protocols.

\section{Study of $H L A-A, H L A-B$ and $H L A-D R B 1$ alleles}

DNA extraction was carried out by standard procedures from fresh whole blood samples collected in anticoagulant EDTA. Alleles of $H L A-A, H L A-B$ and HLA-DRB1 were studied using Polymerase chain reaction followed by hybridization with sequence specific oligonucleotide probes (SSOPs) as described earlier [17] using a bead-based technology (Luminex, Austin, Tx) following Manufacturer's instructions (Labtype SSO kit from One Lambda, Canoga Park, USA). The latest nomenclature for the HLA system was used to designate the alleles of the three loci studied [18].

\section{Statistical analysis}

Frequencies of alleles in the patient samples were compared with their respective unaffected controls using Chi-square analysis and the strength of associations was estimated by odds ratio (OR) and 95\% confidence interval using Stata 9.2 statistical program. Fisher's exact test was used when the numbers were five or less in any group i.e. in cases or controls for any allele. In such cases, Odds ratios were calculated using Woolf's method [19] with Haldane's [20] modification as described earlier [21].

\section{Type 1 diabetes}

Type 1 diabetes (T1D) is an incurable, multi-factorial and complex autoimmune disorder characterized by the loss of insulin producing beta cells of the pancreas. This results in abnormal metabolism of glucose that may be detrimental for several other complications like ketoacidosis, retinopathy, nephropathy and even cardio-vascular diseases and pre-mature deaths [22]. World-wide disease affects 1 in 300-400 children [23]. The incidence in South India has been reported to be 10.5/100,000/year [24]. In North India, a higher prevalence in urban 
$(26.6 / 100,000)$ as compared to rural areas $(4.27 / 100,000)$ has been reported with a total prevalence of $10.20 / 100,000$. T1D develops as a result of complex interaction of many genetic and environmental factors leading to autoimmune destruction of the insulin producing Pancreatic Beta cells. While 20 genomic intervals have been implicated for the manifestation of the disease [22], role of an intricate network of the products of these genes cannot be ruled out. However, unraveling different factors involved and how they interact in integrated networks is like solving a zig-saw puzzle which is the aim of our studies [12, 14, 17]. However, in this chapter we will be concentrating on MHC associations and their implications only.

When the patients report to the clinician, he is left with no option but to give daily insulin injections since most of their pancreatic beta cells are already destroyed. So, if we want to stop autoimmune responses in the people who are predisposed to get T1D, we need to identify the prediabetics before the onset of the disease and device ways to inhibit autoimmunity in them. This is possible by using genetic predisposition criteria to get the disease.

We have studied the frequencies of MHC class-I alleles for HLA-B locus and MHC class-II alleles for HLA-DRB1 and DQB1 loci in patients with Type 1 diabetes and normal healthy controls using polymerase chain reaction followed by hybridization with sequence specific oligonucleotide probes (PCR-SSOP). DNAs were isolated from peripheral blood mononuclear cells (PBMCs) from patients and healthy controls using standard protocol. The second and third exons of the HLA-B gene and second exons of HLA-DRB1 and DQB1 genes were amplified using PCR and hybridized with oligonucleotide probes and the hybridization pattern with different probes was used to identify the alleles present in a sample. The results showed that $H L A-B^{*} 08\left(\mathrm{p}<7.8 \times 10^{-13}\right.$, Odds Ratio $\left.(\mathrm{OR})=3.3\right), H L A-B^{*} 50\left(\mathrm{p}<4.2 \times 10^{-21}, \mathrm{OR}=\right.$ 7.5), HLA-B*58 ( $\left.\mathrm{p}<3.3 \times 10^{-6}, \mathrm{OR}=2.6\right), H L A-D R B 1^{*} 03: 01\left(\mathrm{p}<1.7 \times 10^{-35}, \mathrm{OR}=13.2\right), D R B 1^{*} 04: 01$ $(\mathrm{p}<0.00001, \mathrm{OR}=5.4)$, and $\mathrm{DRB1}{ }^{*} 04: 05(\mathrm{p}<0.00001, \mathrm{OR}=16.01)$, were significantly increased in the patients (Figure 1a, b) as compared to controls. We had earlier compared the results of the T1D patients with 91 healthy controls [14], however, now we have compared the results of T1D samples with 902 healthy controls, with the same results reinforcing our earlier data. These results were in concordance with earlier studies in North Indians [25-29]. However, we also observed $D R B 1^{*} 07: 01\left(\mathrm{p}<8 \times 10^{-6}, \mathrm{OR}=0.19\right)$ to be significantly decreased in the patients as compared to controls. In our earlier study when we had less number of controls, we observed $D R B 1^{*} 04: 03(\mathrm{p}<0.02, \mathrm{OR}=0.25)$ and $D R B 1^{*} 04: 04(\mathrm{p}<0.05, \mathrm{OR}=0.2)$ also to be significantly reduced in the patients [14], however, when we increased the number of controls to 902 , this finding did not remain significant, although $D R B 1^{*} 04$ :03 and $D R B 1^{*} 04$ :04 were reduced in the patients but not significantly. We did not find any significant reduction of HLA-DR2 which has been shown to confer strong protection from T1D in most ethnic groups [30, 31] probably because the DR2 haplotype which has been shown to be protective i.e., DRB1*15:01$D Q B 1^{*} 06: 02$, was observed with a low frequency of only $1.06 \%$ in North Indians [21]. On the other hand, we observed a marginally increased frequency of $D R B 1^{*} 15: 01$ and reduced frequency of $D R B 1^{*} 15: 06$ in patients as compared to controls, which did not remain significant when $p$ was corrected for the number of alleles tested for DRB1 locus. DRB1*04:03 has been shown to be associated with protection in a Belgian study on T1D [32]. Our results are in concordance with studies on T1D patients from Sardinia, black population from Zimbabwe, 
Lithuania, Czecks, Lebanese, Brazilians and African Americans where DRB1*03:01, $D R B 1^{*} 04: 01$ and $D R B 1^{*} 04: 05$ have been shown to be associated with the disease [33-40].

a

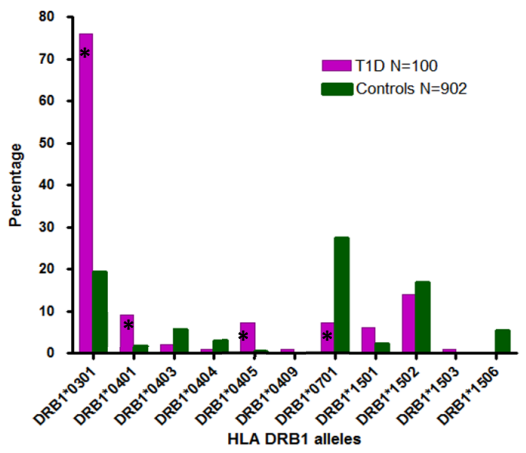

d

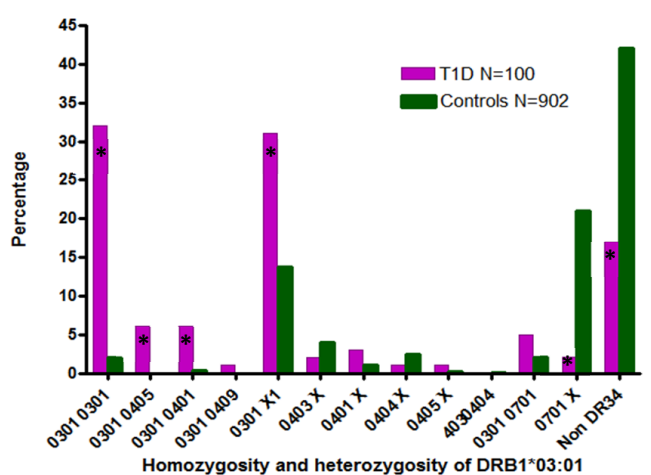

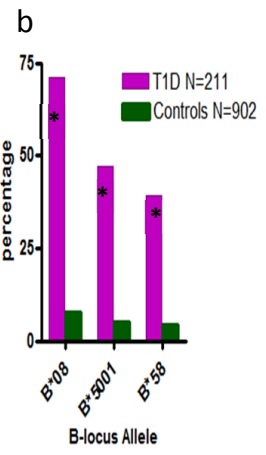

e
C

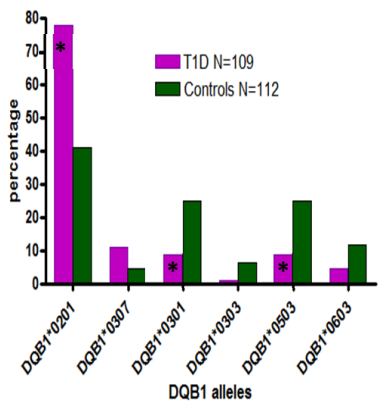

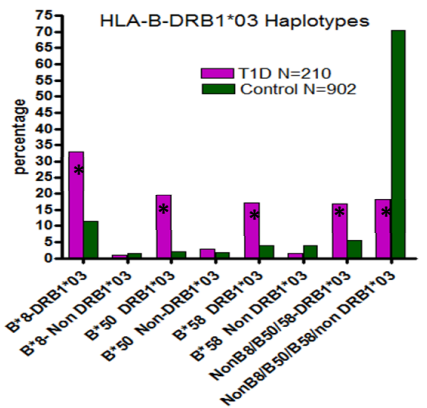

Rani et al., Tissue Antigens, 2004, Kumar et al., Tissue Antigens , 2007

Figure 1. Distribution of HLA-DRB1, HLA-B and DQB1 alleles in Type 1 diabetes and healthy controls. a. HLA-DRB1 alleles significantly increased or decreased in T1D are shown. DRB 1*03:01, ${ }^{*} 04: 01$ and ${ }^{*} 04: 05$ are significantly increased and $D R B 1^{*} 07: 01$ is significantly reduced in T1D as compared to controls. b. HLA-B*08, $B^{*} 50: 01$ and $B^{*} 58$ are significantly increased in T1D as compared to controls C. DQB1*02:01 is significantly increased and $D Q B 1 * 03: 01$ and $D Q B 1 * 05: 03$ are significantly reduced in T1D as compared to controls. d. Homozygous $D R B 1 * 03: 01$ and heterozygous $D R B 1{ }^{*} 03: 01$ with ${ }^{*} 04: 01,{ }^{*} 04: 05$ or any other allele $\left({ }^{*} 0301, X\right)$ are significantly increased in T1D as compared to controls. e. HLA-B-DRB $1{ }^{*} 03$ haplotypes in T1D patients and controls. * denotes alleles that show statistically significant increase or decrease in the frequencies of the depicted alleles.

HLA-DRB1 and DQB1 are in strong linkage disequilibrium. We also studied the alleles of $D Q B 1$ locus. $D Q B 1^{*} 02: 01$ which is linked to $D R B 1^{*} 03: 01$ was significantly increased $\left(\mathrm{p}<1 \times 10^{-8}, \mathrm{OR}=5.08\right)$ in patients (Figure 1c). However $D Q B 1^{*} 03: 02$ and $D Q B 1^{*} 03: 07$, alleles linked with $D R B 1^{*} 04: 01, D R B 1^{*} 04: 03, D R B 1^{*} 04: 04$ and $D R B 1^{*} 04: 05$ were not significantly increased in the patients because two of these alleles DRB1*04:01 and DRB1*04:05 were increased in the patients and the other two DR4 alleles DRB1*04:03 and DRB1*04:04 were reduced in the patients. $D Q B 1^{*} 03: 01\left(\mathrm{p}<6 \times 10^{-4}, \mathrm{OR}=0.27\right)$ and $D Q B 1^{*} 05: 03\left(6 \times 10^{-4}, \mathrm{OR}=0.28\right)$ were reduced in the patients [14]. 
Figure $1 \mathrm{~d}$ shows the homozygosity and heterozygosity of $D R B 1^{*} 03: 01$ and $D R B 1^{*} 04$ alleles significantly increased in T1D. Homozygous DRB1*03:01 ( $\left.\mathrm{p}<4.6 \mathrm{X} 10^{-39}, \mathrm{OR}=23.1\right)$, heterozygous DRB1*03:01/*04:05 ( $\left.\mathrm{p}<5.5 \times 10^{-6}, \mathrm{OR}=124.2\right)$ and $D R B 1^{*} 03: 01{ }^{*} 04: 01(\mathrm{p}<0.0001, \mathrm{OR}=17.6)$ were significantly increased in the patients as compared to controls. Heterozygous 03:01/X (i.e. any other allele $)\left(\mathrm{p}<5.9 \times 10^{-6}, \mathrm{OR}=2.8\right)$ was also significantly increased in the patients as compared to controls. Heterozygous DRB1*07:01/X $\left(\mathrm{p}<1.3 \times 10^{-7}, \mathrm{OR}=0.09\right)$ were significantly reduced in the T1D patients as compared to controls suggesting their protective role. Thirty two percent of the patients studied were homozygous for $D R B 1^{*} 0301$ as compared to $2 \%$ of the controls and this difference was highly significant. Homozygosity of $D Q B 1^{*} 02: 01$ was significantly $\left(\mathrm{p}<1 \times 10^{-5}, \mathrm{OR}=5.4\right)$ increased in the patients. $D Q B 1^{*} 03: 02$ which was not significantly increased in the patients, showed a significant increase in heterozygous combination with $D Q B 1^{*} 0201$ $\left(\mathrm{p}<3 \times 10^{-5}, \mathrm{OR}=34.16\right)[14]$. In fact none of the controls had $D Q B 1^{*} 0201 /{ }^{*} 0302$ heterozygous combination [14]. In a Swedish study, $D Q A 1^{*} 0301 / D Q B 1^{*} 0302$ and heterozygous combinations of $D Q A 1^{*} 0301 / D Q B 1^{*} 0302$ and $D Q A 1^{*} 0201 / D Q B 1^{*} 0501$ have been shown to confer the highest susceptibility [41]

Figure 1 e shows the $H L A-B-D R B 1$ haplotypes that were significantly increased in T1D patients. HLA alleles are very closely linked to each other in such a way that the haplotypes are inherited en-bloc. Three HLA-DRB1*03 haplotypes, $B^{*} 08-D R B 1^{*} 03: 01\left(\mathrm{p}<1 \times 10^{-14}, \quad \mathrm{OR}=3.7\right), \quad B^{*} 50$ $D R B 1^{*} 03: 01\left(\mathrm{p}<8 \times 10^{-24}, \mathrm{OR}=11.2\right)$ and $B^{*} 58-D R B 1^{*} 03: 01\left(\mathrm{p}<1.4 \times 10^{-12}, \mathrm{OR}=5.1\right)$ and $D R B 1^{*} 03: 01$ haplotypes with non $B^{*} 8 / B^{*} 50 / B^{*} 58$ alleles $\left(\mathrm{p}<2.8 \times 10^{-8}\right.$, OR=3.4) were significantly increased in the patients as compared to controls. On the other hand non- $B^{*} 8 / B^{*} 50 / B^{*} 58$-non $D R B 1^{*} 03: 01$ haplotypes were significantly reduced $\left(\mathrm{p}<1.5 \times 10^{-44}, \mathrm{OR}=0.09\right)$ in T1D patients as compared to controls [12].

Thus our studies show a significant increase of HLA class-I and II alleles which may have a role in auto-antigen presentation to $\mathrm{CD} 8^{+}$and $\mathrm{CD} 4^{+} \mathrm{T}$ cells respectively.

\section{Vitiligo}

Vitiligo is a depigmenting disorder of the skin caused by autoimmune destruction of pigment producing cells called melanocytes. It effects $0.5-1 \%$ of the world population [42], while in India the incidence varies from 0.25 to $2.5 \%[43,44]$ in most ethnic groups, however, it has been reported to be $8.8 \%$ in populations from western states of Gujarat and Rajasthan [45]. Vitiligo manifests in several forms which can be broadly classified in two clinical subtypes: generalized and localized [42]. While precise etiology of vitiligo is not very well understood, several hypotheses have been proposed which include autoimmune [46], neural [47], auto-cytotoxic [48] and genetic hypotheses [49]. However, autoimmune hypothesis gets credence due to cooccurrence of other autoimmune diseases in vitiligo patients in some cases, presence of auto reactive $\mathrm{T}$ cells and circulating auto-antibodies in the patients [46, 50-55]. The role of genetic factors has been suggested due to the fact that $7 \%$ of first-degree relatives of vitiligo develop the disease. [56, 57]. 
Recent genome wide studies [58,59] have shown that several single nucleotide polymorphisms (SNPs) in the MHC region were significantly associated with the disease. Using imputation based on the previous studies done on associations of HLA, the authors showed that certain HLA-class-I alleles were associated with vitiligo but they could not impute HLA class-II alleles. [58]. As mentioned before MHC is the most polymorphic system of the human genome. With such a great diversity at each locus, linkage disequilibrium (LD) of HLA alleles with di-allelic SNPS may not be appropriate since several HLA alleles may be in LD with one or the alternate SNP. Thus the derivation based on these LDs may not be accurate especially in the populations from where no previous HLA data is available i.e. if there is no HLA data available it would be impossible to determine the linkage disequilibrium of HLA alleles with di-allelic SNPs. So, we conducted a very robust study on a sample size of 1404 vitiligo cases consisting of 1097 generalized and 307 localized vitiligo cases and 902 unaffected controls from North India for the alleles at $H L A-A,-B$, (class-I) and -DRB1 (ClassII) loci using molecular methods and also replicated the study on 355 cases (250 generalized and 105 localized) and 441 controls from Gujarat, a state in west of India [15]. We also reported differences in the amino acid signatures of peptide binding pockets of the HLA molecules in vitiligo patients as compared to controls [15].

Our study showed a lot of diversity in number and frequencies of HLA alleles in patients and controls, with 78, 160 and 106 alleles in cases and 68, 111 and 94 alleles in controls for HLA-A, $-B$ and $-D R B 1$ loci respectively from North India. Similar diversity was observed in the replication study as well. However, $H L A-A^{*} 33: 01\left(\mathrm{p}<1.21 \times 10^{-15}, \mathrm{OR}=2.57\right.$ in North Indians and $\mathrm{p}<0.008, \mathrm{OR}=1.69$ in Gujaratis), $B^{*} 44: 03 \quad\left(\mathrm{p}<7.05 \times 10^{-27}, \mathrm{OR}=3.53\right.$ in North Indians and $\mathrm{p}<1.54 \times 10^{-8}, \mathrm{OR}=3.13$ in Gujaratis) and $D R B 1^{*} 07: 01\left(\mathrm{p}<3.16 \times 10^{-30}, \mathrm{OR}=2.8\right.$ in North Indians and $\mathrm{p}<9.81 \times 10^{-15}, \mathrm{OR}=3.19$ in Gujaratis) were significantly increased in both initial and replication study (Figure 2), suggesting these alleles are the markers for Vitiligo in both North India and Gujarat. These associations were significant irrespective of the age at onset or the gender of the cases. So, to determine which $H L A$ alleles have primary association, we sequentially deleted samples having $D R B 1^{*} 07: 01, A^{*} 33: 01$ and $B^{*} 44: 03$ from both the case and control groups and then analysed the data for remainder alleles. The analysis showed that association of $D R B 1^{*} 07: 01$ with vitiligo seemed to be primary because in the absence of $D R B 1^{*} 07: 01$, the classI alleles $A^{*} 33: 01$ and $B^{*} 44: 03$ did not remain significantly increased. However, in the absence of $A^{*} 33: 01$ and $B^{*} 44: 03, D R B 1^{*} 07: 01$ still remained significantly increased in both the populations studied. The basic predisposing alleles in both localized and generalized vitiligo are same; however, similarities with the controls in terms of allele frequencies of some alleles and amino acid signature of the DR beta chain (figure 3) seem to be protective from generalized distribution of the lesions in localized vitiligo[15].

Removal of $D R B 1^{*} 07: 01$ from both patients and control groups resulted in removal of all the samples that had $A^{*} 33: 01$ and $B^{*} 44: 03$, suggesting that these alleles being on the same chromosome may be making a haplotype, such that when samples with $D R B 1^{*} 07: 01$ are removed they also get removed simultaneously. To prove that we estimated the HLA haplotype frequencies using the expectation-maximization (EM) algorithm [60, 61] using Arlequin Ver 3.5 (http://cmpg.unibe.ch/software/arlequin35/). Haplotype analysis for three loci showed 
North Indians
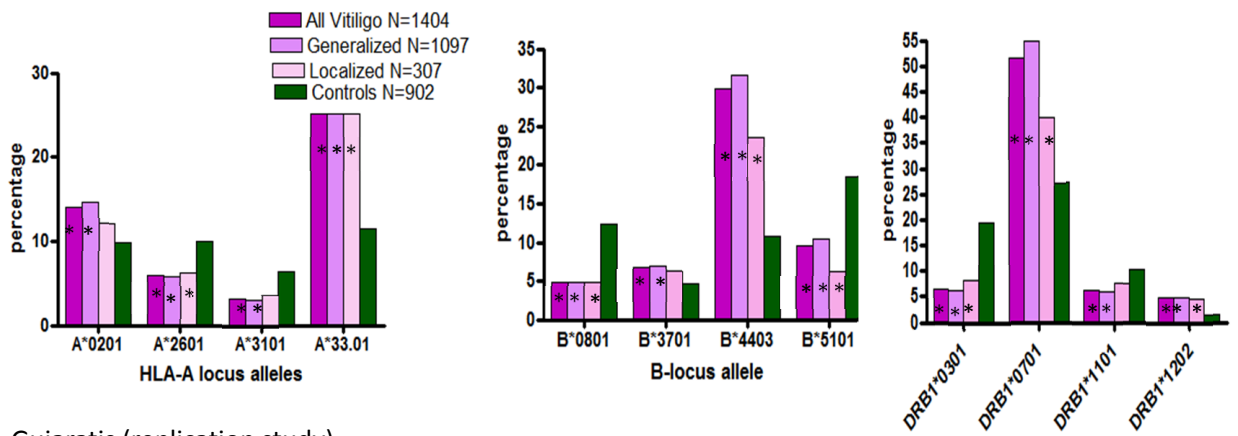

Gujaratis (replication study)
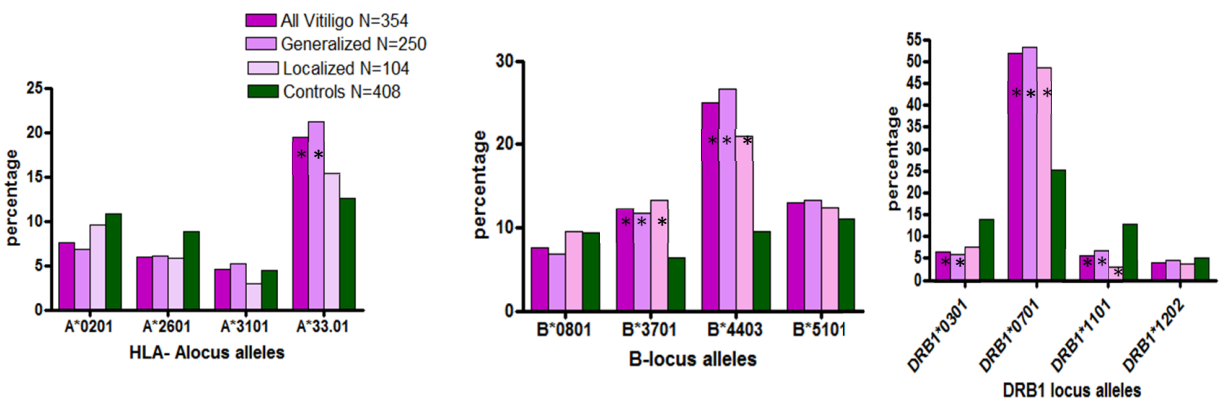

Singh et al., Journal of Investigative Dermatology,2012

Figure 2. HLA-A, B and DRB1 loci alleles significantly increased in all vitiligo, generalized vitiligo and localized vitiligo patients when compared with healthy controls in North Indian and Gujarat patients. * denotes alleles that show statistically significant increase or decrease in the frequencies of the depicted alleles.

haplotypes $A^{*} 33: 01-B^{*} 44: 03-D R B 1^{*} 07: 01 \quad\left(\mathrm{p}<8.75 \times 10^{-23}, \mathrm{OR}=6.21\right.$ in North Indians and $\mathrm{p}<0.000016, \mathrm{OR}=3.65$ in Gujaratis) and $A^{*} 24: 02-B^{*} 44: 03-D R B 1^{*} 07: 01 \quad(\mathrm{p}<0.0019, \mathrm{OR}=3.83$ in North Indians and $\mathrm{p}<0.0034, \mathrm{OR}=7.73$ in Gujaratis) were significantly increased and $A^{*} 26: 01$ $B^{*} 08: 01-D R B 1^{*} 03: 01$ was significantly reduced $(\mathrm{p}<0.00005, \mathrm{OR}=0.33$ in North Indians and $\mathrm{p}<0.0007, \mathrm{OR}=0.15$ in Gujaratis) in vitiligo patients in both the initial study as well as in the replication study. Analysis of two-locus haplotypes revealed haplotypes $A^{*} 33: 01$ $D R B 1^{*} 07: 01\left(\mathrm{p}<6.97 \times 10^{-26}, \mathrm{OR}=6.55\right.$ in North Indians and $\mathrm{p}<0.00001, \mathrm{OR}=3.59$ in Gujaratis $)$ and $B^{*} 44: 03-D R B 1^{*} 07: 01\left(\mathrm{p}<2.4 \times 10^{-29}, \mathrm{OR}=4.01\right.$ in North Indians and $\mathrm{p}<1.84 \times 10^{-14}, \mathrm{OR}=6.34$ in Gujaratis) was significantly increased and $A^{*} 26: 01-D R B 1^{*} 03: 01$ was significantly reduced $(\mathrm{p}<0.00005, \mathrm{OR}=0.33$ in North Indians and $\mathrm{p}<0.0007, \mathrm{OR}=0.15$ in Gujaratis) in vitiligo cases in both initial and replication study[15].

We further studied the amino acid signatures of the peptide binding pockets of DRB1 in vitiligo cases and unaffected controls Eleven residues representing integral parts of peptide binding pockets of DR beta chain were analysed at positions 26, 28, 30, 37, 47, 67, 70, 71, 74, 77 and 86 [62]. The protein sequences were downloaded for all the alleles observed from the HLA database (http://www.ebi.ac.uk/cgi-bin/imgt/HLA/align.cgi) and the amino acids present at 


\begin{tabular}{|l|l|l|l|l|l|l|l|l|l|l|l|}
\hline Position & $\mathbf{2 8}$ & $\mathbf{3 0}$ & $\mathbf{3 0}$ & $\mathbf{3 7}$ & $\mathbf{4 7}$ & $\mathbf{6 7}$ & $\mathbf{7 0}$ & $\mathbf{7 1}$ & $\mathbf{7 4}$ & $\mathbf{7 7}$ & $\mathbf{8 6}$ \\
\hline Amino Acid & E & L & R & F & Y & I & D & R & Q & T & G \\
\hline North Indians All Vitiligo & & & & & & & & & & & \\
\hline Gujaratis All Vitiligo & & & & & & & & & & \\
\hline North Indian Generalized & & & & & & & & & & & \\
\hline Gujaratid Generalized & & & & & & & & & & \\
\hline North Indian Localized & & & & & & & & & & \\
\hline Gujarati Localized & & & & & & & & & & \\
\hline
\end{tabular}

\begin{tabular}{|l|l|l|l|l|l|l|l|l|l|l|l|l|}
\hline Position & $\mathbf{2 8}$ & $\mathbf{3 0}$ & $\mathbf{3 0}$ & $\mathbf{3 7}$ & $\mathbf{4 7}$ & $\mathbf{6 7}$ & $\mathbf{7 0}$ & $\mathbf{7 1}$ & $\mathbf{7 4}$ & $\mathbf{7 4}$ & $\mathbf{7 7}$ & $\mathbf{8 6}$ \\
\hline Amino Acid & D & Y & C & S & F & L & Q & K & A & R & N & V \\
\hline North Indians All Vitiligo & & & & & & & & & & & & \\
\hline Gujaratis All Vitiligo & & & & & & & & & & & & \\
\hline North Indian Generalized & & & & & & & & & & & \\
\hline Gujaratid Generalized & & & & & & & & & & & \\
\hline North Indian Localized & & & & & & & & & \\
\hline Gujarati Localized & & & & & & & & & \\
\hline
\end{tabular}

Significantly increased $<0.009$ to $10^{-6}$

Significantly increased $p<0.01$ to 0.05

Non significant

Significantly reduced $p<0.01$ to 0.05

Significantly reduced $p<0.009$ to $10^{-6}$

Figure 3. Amino acid signatures for the peptide binding pockets of HLA molecules for DR beta1 chain in all vitiligo, generalized vitiligo and localized vitiligo patients from North India and Gujarat. Amino acids shown in red are significantly increased in vitiligo patients while amino acids shown in green are significantly reduced in vitiligo patients as compared to controls and those in black are not significantly different from controls (Singh et al., JID, 2012).

the aforesaid positions were compared in patients with controls. Figure 3 shows the amino acid residues at the aforesaid positions that were either significantly increased or decreased in all vitiligo patients, generalized and localzed vitiligo patients when compared with controls. The results show that $\mathrm{Glu}^{28 \beta}$, $\mathrm{Leu}^{30 \beta} / \mathrm{Arg}^{30 \beta} \mathrm{Phe}^{37 \beta}, \mathrm{Tyr}^{47 \beta}, \mathrm{Ile}^{67 \beta}, \mathrm{Asp}^{70 \beta}, \mathrm{Arg}^{71 \beta}, \mathrm{Gln}^{74 \beta}, \mathrm{Thr}^{77 \beta}$ and $\mathrm{Gly}^{86 \beta}$ make the molecular signature of the peptide binding pockets of DRB1 for predisposition to develop vitiligo in both the initial as well as in the replication study (Figure 3). Asp ${ }^{28 \beta}, \mathrm{Tyr}^{30 \beta /}$ $\mathrm{Cys}^{30 \beta}, \mathrm{Ser}^{37 \beta}, \mathrm{Phe}^{47 \beta}, \mathrm{Leu}^{67 \beta}, \mathrm{Gln}^{70 \beta}, \mathrm{Lys}^{71 \beta}, \mathrm{Ala} / \mathrm{Arg}^{74 \beta}, \mathrm{Asn}^{77 \beta}$ and $\mathrm{Val}^{86 \beta}$ make the molecular signature for the protection from Vitiligo in both North India and Gujarat. [15].

We observed subtle differences in the molecular signatures of the peptide binding pockets of DR beta chain in localized and generalized vitiligo. Localized vitiligo patients show similarities in the amino acid signatures with not only generalized vitiligo but also with healthy controls probably responsible for localized distribution of the lesions in them. Amino acid signature at positions $\mathrm{Glu}^{28 \beta}$, $\mathrm{Leu}^{30 \beta}, \mathrm{Phe}^{37 \beta}, \mathrm{Tyr}^{47 \beta}$ and $\mathrm{Gln}^{74 \beta}$ in the localized vitiligo patients is similar to 
generalized vitiligo in both the initial and replication study. However, the amino acid signature similar to healthy controls were observed at positions $\mathrm{Arg}^{30 \beta} / \mathrm{Cys}^{30 \beta}, \mathrm{Ser}^{37 \beta}, \mathrm{Ile}^{67 \beta} / \mathrm{Leu}^{67 \beta} \mathrm{Asp}^{70 \beta}$, $\mathrm{Ala}^{74 \beta}$ in North Indians and $\mathrm{Cys}^{30 \beta}, \mathrm{Ser}^{37 \beta}, \mathrm{Asp}^{70 \beta}, \mathrm{Arg}^{71 \beta} / \mathrm{Lys} \mathrm{Ser}^{71 \beta}, \mathrm{Ala}^{74 \beta} / \mathrm{Arg}^{74 \beta}$ and $\mathrm{Thr}^{77 \beta} /$ $\mathrm{Asn}^{77 \beta}$ in Gujaratis [15].

Most of the studies previously have been done on Generalized vitiligo which has been considered to be an autoimmune disease. We showed for the first time that both generalized and localized vitiligo have the same predisposing MHC alleles i.e., $B^{*} 44: 03$ and DRB1*07:01 in both the populations studied. Association of $M H C$ alleles with localized vitiligo clearly suggests an autoimmune etiology of the disease due to antigen presenting function of the MHC molecules. Thus there seems to be a need to re-look at the aetiopathogenesis of localized vitiligo in light of our results. While it may be an autoimmune disorder, similarities with unaffected controls in terms of HLA alleles and amino acid signature of the peptide binding pockets of DR beta chain may be contributing to the localized distribution of the lesions [15].

\section{Idiopathic hypoparathyroidism}

Idiopathic hypoparathyroidism $(\mathrm{IH})$ is a rare endocrine disease where parathyroid gland is functionally impaired resulting in subnormal PTH secretion, hypocalcemia, hyperphosphatemia and associated complications [63]. While it may be an autoimmune disorder [63], there is hardly any evidence to confirm the autoimmune etiology of the disease. Since there was no comprehensive study on the immunogenetic basis of IH, we studied the association of HLA class- $I$ and II alleles in a large group of North Indian patients $(\mathrm{N}=134)$ with $\mathrm{IH}[16,64-70]$ and compared them to 902 healthy controls from the same ethnic background. We also reported significant differences in the amino acid signatures of peptide binding pockets of the HLA molecules in patients with IH as compared with controls [16].

Just like vitiligo, we observed diversity in number and frequencies of HLA alleles with 23, 40 and 44 alleles in patients for $H L A-A,-B$, and $-D R B 1$ loci, respectively. However, specific alleles at these loci were found to be predisposing. HLA- $A^{*} 26: 01\left(p<1.71 \times 10^{-34}\right.$, OR $\left.=9.29\right), H L A-$ $B^{*} 08: 01\left(p<8.19 \times 10^{-6}, \mathrm{OR}=2.59\right)$, and HLA-DRB1*03:01 $(p<0.013, \mathrm{OR}=1.67)$ and HLA$D R B 1^{*} 12: 02(p<0.0046, \mathrm{OR}=3.52)$ were significantly increased in IH when compared with healthy controls. However, alleles HLA- $A^{*} 01: 01(p<0.039, \mathrm{OR}=0.60), H L A-A^{*} 03: 01(p<0.004$, $\mathrm{OR}=0.33), H L A-B^{*} 15: 01(p<0.0038, \mathrm{OR}=0.17)$ and $H L A-B^{*} 57: 01(p<0.0074, \mathrm{OR}=0.3)$ were significantly reduced in IH as compared with controls (Figure 4a). Since HLA-A*26:01 showed the highest significance, we studied whether any other allele was significantly increased in the absence of $H L A-A^{*} 26: 01$. So, all the samples with $A^{*} 26: 01$ were removed from both cases and controls and then analysis was done for significant differences in frequencies of the remainder alleles. In the absence of $H L A-A^{*} 26: 01$, no other allele showed any significant differences [16].

Associations of $A^{*} 26: 01$ and $B^{*} 08: 01$ with $\mathrm{IH}$ were significant irrespective of the gender and age at onset of the disease. To investigate whether there was any association of HLA alleles with associated clinical autoimmunity in $\mathrm{IH}$, patients were categorized into two groups, those with associated clinical autoimmunity and those without. While $H L A-A^{*} 26: 01$ was signifi- 
cantly increased in both the groups as compared with controls, $H L A-B^{*} 08: 01$ and $D R B 1^{*} 12: 02$ were significantly increased in patients without any associated clinical autoimmunity when compared with controls [16].
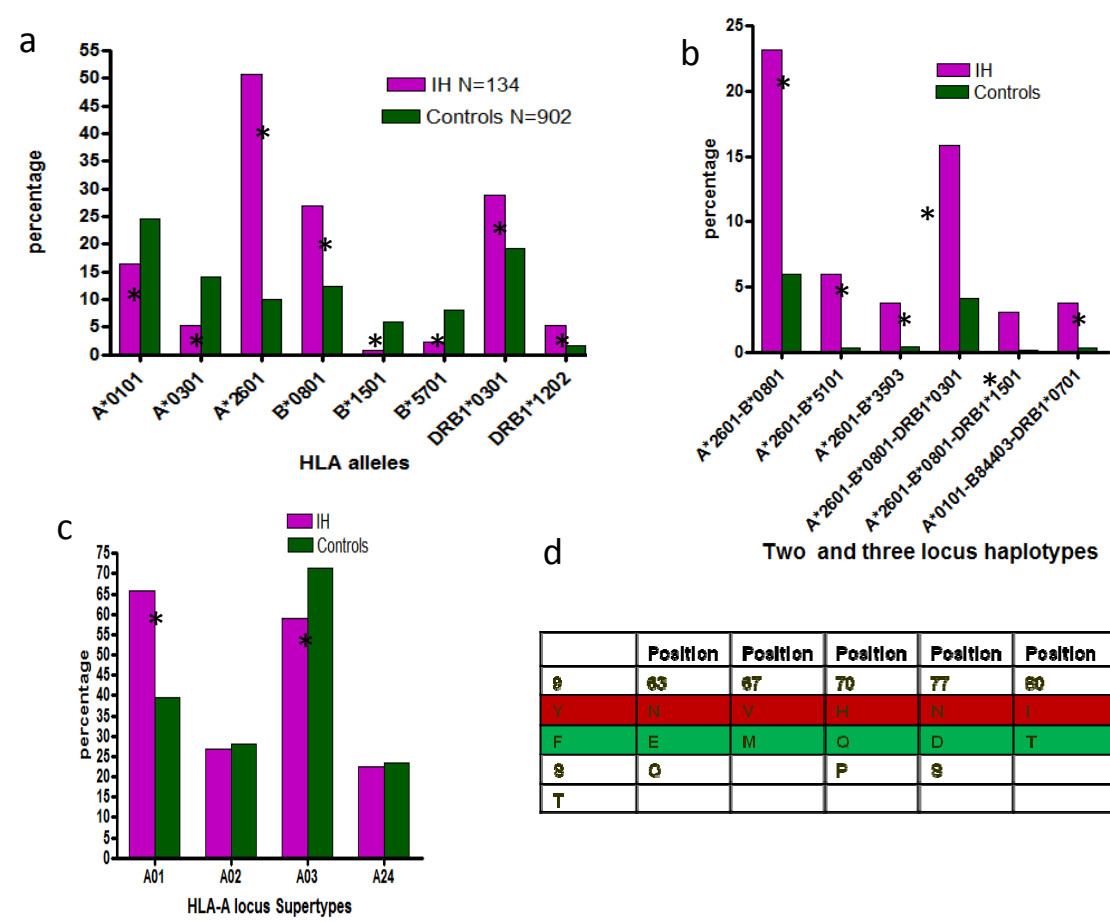

Goswami et al., Journal of clinical Endocrinology and
Metabolism, 2012

Figure 4. HLA-A, B and DRB1 loci alleles significantly increased in idiopathic hypoparathyroidism patients when compared with healthy controls in North Indian patients. * denotes alleles that show statistically significant increase or decrease in the frequencies of the depicted alleles.

We constructed HLA haplotypes for HLA-A-B-DRB1 and HLA-A-B and HLA-A-DRB1 for 133 cases and 902 controls using Arlequin 3.5 program (http://cmpg.unibe.ch/software/arlequin35/). Haplotype HLA- $A^{*} 26: 01-B^{*} 08: 01-D R B 1^{*} 03: 01\left(p<4.47 \times 10^{-8}\right.$, OR $\left.=4.38\right)$, was significantly increased in cases as compared with controls. Two locus haplotype analysis (figure $4 b)$ showed haplotypes $A^{*} 26: 01-B^{*} 08: 01\left(p<1.48 \times 10^{-11}, \mathrm{OR}=4.72\right), A^{*} 26: 01-B^{*} 51: 01\left(p<7.59 \times 10^{-6}\right.$,

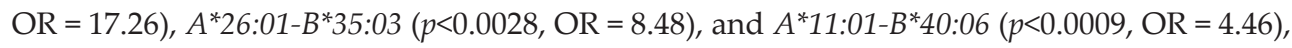
were significantly increased in IH as compared to controls. However, the association of $A^{*} 26: 01$ with IH seems to be primary since in the absence of $A^{*} 26: 01$, none of the other alleles like $B^{*} 08: 01, B^{*} 51: 01$ or $D R B 1^{*} 03: 01$ remained significantly different suggesting that the significant increase in these alleles is due to their being in linkage disequilibrium with the $A^{*} 26: 01$ [16]. 
MHC molecules are extremely polymorphic, however, alleles with similar peptide binding pockets may be clustered in one group [6], called supertypes, such that HLA molecules in one supertype may present similar peptides[16]. Assignment of alleles in the supertypes have been done based on published motifs, binding data, shared repertoires of binding peptides and the amino acid sequences of different alleles at the peptide binding pockets [6]. Supertype A01 (which includes $A^{*} 26: 01$ ) was significantly increased in $\mathrm{IH}$ with $65.67 \%$ of the patients as compared to $39.36 \%$ of the controls having this supertype (figure $4 \mathrm{c}$ ). However, $A^{*} 26: 01$ was observed only in $50.75 \%$ of the patients as compared to $9.98 \%$ of the controls. About $15 \%$ of the IH cases had different alleles of A01 supertype (other than $A^{*} 26: 01$ ), which did not show statistically significant differences due to small numbers. Significant increase of A01 supertype suggests that similar auto-antigenic peptides may be getting presented by different MHC molecules which belong to the supertype $[6,16]$.

While the amino acid residue at a particular position in different alleles in a supertype may not be the same, they would be similar in nature such that they would bind similar peptides. For instance, all the alleles falling in supertype A01 will bind small and aliphatic residues in the B pocket and aromatic and large hydrophobic residues in F pocket [6]. Thus, the nature of the shared amino acids and not amino acid per se constitutes the molecular signatures of the peptide binding groove of different alleles in a supertype.

The peptide binding groove of the MHC class-I molecules contain small pockets where the side chains of complimentary residues of the peptide bind [4]. Pockets B (key residues at positions 9, 45, 63, 67, 70 and 99) and $\mathrm{F}$ (key residues at positions 77, 80, 81 and 116) of alpha chain are the main anchors which engage the peptides at its amino acid position 2 and the $\mathrm{C}$ terminus [6]. Since we observed a significant increase in an HLA-A locus allele (HLA$\left.A^{*} 26: 01\right)$, we analysed the amino acid signatures of the peptide binding groove of the alleles of A-locus to check for shared peptide binding specificity. For this purpose, the protein sequences of the HLA-A locus alleles were downloaded from the HLA database as mentioned for the vitiligo study and the amino acids present at the aforesaid positions were compared in patients with controls. We observed that $\mathrm{Tyr}^{9 \alpha}, \mathrm{Asn}^{63 \alpha}, \mathrm{Val}^{67 \alpha}, \mathrm{His}^{70 \alpha}, \mathrm{Asn}^{77 \alpha}$, $\mathrm{Ile}^{80 \alpha}$ and $\mathrm{Ala}^{81 \alpha}$ make the molecular signature for HLA-A peptide binding pockets for predisposition to IH, however, $\mathrm{Phe}^{9 \alpha}, \mathrm{Glu}^{63 \alpha}, \mathrm{Met}^{67 \alpha}, \mathrm{Gln}^{70 \alpha}, \mathrm{Asp}^{77 \alpha}$, $\mathrm{Thr}^{80 \alpha}$ and $\mathrm{Leu}^{81 \alpha}$ make the molecular signature for negative association with the disease (Figure $4 \mathrm{~d}$ ). While the most significant association was derived from $H L A-A^{*} 26: 01$, peptide binding grooves of other alleles shared some of the residues with the peptide binding grove of $H L A-A^{*}$ 26:01 (Figure 5)[16].

MHC is the most polymorphic system of the man with more than 6000 alleles for different loci. With such a great diversity, association of particular $M H C$ alleles with a disease has functional implications due to the antigen presenting function of the MHC. The peptides presented by the MHC molecules have allele specific motifs [4]. The affinity of the peptide to a particular MHC molecule is determined by the amino acid residues present in peptide binding pockets of the peptide binding groove. Shared amino acids in the peptide binding pockets have been demonstrated in autoimmune diseases like Type 1 diabetes [71], rheumatoid arthritis [72] and thyroiditis [62]. Investigation of amino acid signatures for the peptide binding pockets of HLAA and HLA-B alpha chain and HLA-DR beta chain revealed specific molecular signatures for 


\begin{tabular}{|c|c|c|c|c|c|c|c|c|c|}
\hline HLA-A & $\mathrm{N}=259$ & Position & Position & Position & Position & Position & Position & Position & supertypes \\
\hline *Alleles & No. & 9 & 63 & 67 & 70 & 77 & 80 & 81 & \\
\hline$A * 26: 01$ & 68 & $y$ & $\mathrm{~N}$ & V & $\mathrm{H}$ & $\mathrm{N}$ & 1 & $\mathrm{~A}$ & $\mathrm{~A} 01$ \\
\hline$A^{*} 0101$ & 22 & $\mathrm{~F}$ & $\mathrm{E}$ & $\mathrm{M}$ & $\mathrm{H}$ & N & $T$ & L & $\mathrm{A} 01$ \\
\hline$A * 29: 01$ & 5 & $T$ & Q & v & $\mathrm{Q}$ & N & $T$ & L & $\mathrm{A} 01$ \\
\hline$A * 30: 01$ & 4 & $s$ & $E$ & V & $\mathrm{Q}$ & D & $\mathrm{T}$ & L & $\mathrm{A} 01$ \\
\hline$A^{\star 32: 01}$ & 3 & $\mathrm{~F}$ & $\mathrm{E}$ & v & H & $\mathrm{s}$ & t & $\mathrm{A}$ & $\mathrm{A} 01$ \\
\hline$A^{*} 26: 25 \mathrm{~N}$ & 1 & & N & V & $P$ & N & $T$ & $\mathrm{~L}$ & $\mathrm{~A} 01$ \\
\hline$A * 11: 01$ & 42 & & $\mathrm{E}$ & v & $\mathrm{Q}$ & $D$ & $\mathrm{~T}$ & L & $\mathrm{A} 03$ \\
\hline$A * 68: 01$ & 18 & & $\mathrm{~N}$ & $\mathrm{v}$ & $\mathrm{Q}$ & $\mathrm{D}$ & $T$ & $\mathrm{~L}$ & $\mathrm{~A} 03$ \\
\hline$A * 24: 02$ & 28 & $\mathrm{~s}$ & $E$ & v & $\mathrm{H}$ & $\mathrm{N}$ & 1 & $\mathrm{~A}$ & A24 \\
\hline$A * 23: 01$ & 1 & $\mathrm{~s}$ & $E$ & v & $\mathrm{H}$ & N & 1 & A & A24 \\
\hline$A * 23: 15$ & 1 & $\mathrm{~s}$ & $\mathrm{E}$ & v & $\mathrm{H}$ & $\mathrm{N}$ & 1 & A & A24 \\
\hline$A * 24: 07$ & 1 & s & $\mathrm{E}$ & $\mathrm{v}$ & $\mathrm{Q}$ & $\mathrm{N}$ & 1 & $\mathrm{~A}$ & A24 \\
\hline$A * 02: 06$ & 4 & & $\mathrm{E}$ & $\mathrm{V}$ & $\mathrm{H}$ & $\mathrm{D}$ & $T$ & $\mathrm{~L}$ & $\mathrm{~A} 02$ \\
\hline$A^{*} 02: 05$ & 3 & & $\mathrm{E}$ & v & $\mathrm{H}$ & $D$ & $\mathrm{~T}$ & $\mathrm{~L}$ & $\mathrm{~A} 02$ \\
\hline$A * 33: 01$ & 10 & $\mathrm{~T}$ & N & v & $\mathrm{H}$ & D & $\mathrm{T}$ & $\mathrm{L}$ & $\mathrm{A} 03$ \\
\hline$A * 33: 03$ & 2 & $T$ & & v & $\mathrm{H}$ & $D$ & $\mathrm{~T}$ & $\mathrm{~L}$ & $\mathrm{~A} 03$ \\
\hline$A * 30: 36$ & 1 & $\mathrm{~s}$ & E & $\mathrm{v}$ & Q & D & $T$ & L & $\mathrm{A} 03$ \\
\hline$A * 02: 01$ & 13 & $\mathrm{~F}$ & $E$ & $\mathrm{v}$ & $\mathrm{H}$ & D & $T$ & $\mathrm{~L}$ & $\mathrm{~A} 02$ \\
\hline$A * 02: 11$ & 12 & $\mathrm{~F}$ & $\mathrm{E}$ & v & H & $D$ & $T$ & L & $\mathrm{A} 02$ \\
\hline$A^{*} 02: 03$ & 6 & $\mathrm{~F}$ & $\mathrm{E}$ & $\mathrm{V}$ & $\mathrm{H}$ & $\mathrm{D}$ & $\mathrm{T}$ & $\mathrm{L}$ & $\mathrm{A} 02$ \\
\hline$A * 03: 01$ & 7 & $\mathrm{~F}$ & $\mathrm{E}$ & v & $\mathrm{Q}$ & $D$ & $\mathrm{~T}$ & $\mathrm{~L}$ & $\mathrm{~A} 03$ \\
\hline$A * 31: 01$ & 6 & $\mathbf{T}$ & $\mathrm{E}$ & v & $\mathrm{H}$ & $D$ & $\mathrm{~T}$ & $\mathrm{~L}$ & $\mathrm{~A} 03$ \\
\hline$A * 03: 02$ & 1 & $\mathrm{~F}$ & E & v & Q & D & $T$ & L & $\mathrm{A} 03$ \\
\hline
\end{tabular}

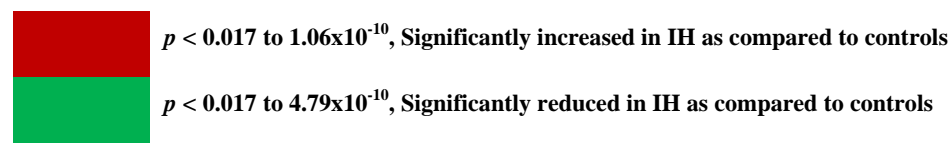

Figure 5. Amino acid signatures (single letter codes) of the peptide binding pockets and HLA supertypes of 23 HLA-A locus alleles observed in $\mathrm{IH}$ cases showing significant increase or decrease in the number of amino acids. $\mathrm{N}=259 \mathrm{indi}-$ cates 259 alleles were observed in 134 patients which were compared with amino acid signatures of 1698 alleles from 902 controls.

predisposition and protection from these diseases. Our data shows that haplotypes $B^{*} 8$ DRB1*03:01, $B^{*} 50-D R B 1^{*} 03: 01$ and $B^{*} 58-D R B 1^{*} 03: 01$ were significantly increased in T1D patients [12]. $A^{*} 26: 01-B^{*} 08: 01-D R B 1^{*} 03: 01$ and $A^{*} 26: 01$ with other B-locus alleles were significantly increased in hypoparathyroidism [16]. And in yet another autoimmune disorder,

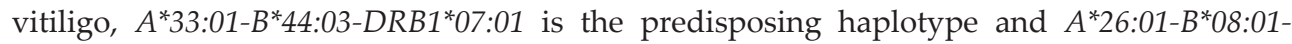
$D R B 1^{*} 03: 01$ seems to be protective haplotype, with $D R B 1^{*} 07: 01$ having primary association with the disease [15]. While in T1D and vitiligo it is the MHC class-II allelesDRB1*03:01 andDRB1*07:01 respectively, which had primary association, in hypoparathyroidism it is the MHC class-I allele $H L A-A^{*} 26: 01$ which has primary association. Interestingly, in T1D $D R B 1^{*} 03: 01$ is predisposing and $D R B 1^{*} 07: 01$ is protective from the disease. However, in vitiligo it is exactly the opposite i.e., $D R B 1^{*} 07: 01$ is predisposing and DRB1*03:01 is protective. 
These data suggest the autoantigenic peptides presented by different MHC molecules are restricted by these common alleles in a population which are associated with the autoimmune disorders. Of about 350 alleles that were observed in the three patient groups and healthy controls, $A^{*} 26: 01$ (9.98\%), $A^{* 33: 01}(11.53 \%), B^{*} 08: 01$ (12.42\%), $B^{*} 44: 03$ (10.75\%), DRB1*03:01 $(19.29 \%)$ and $D R B 1^{*} 07: 01(27.49 \%)$, were quite common alleles in the healthy North Indians that were associated with the three autoimmune disorders discussed above.

Our results suggest affinity of auto-antigenic peptides for predisposing MHC class-II and classI molecules which may be involved in orchestrating (through $\mathrm{CD} 4^{+} \mathrm{T}$ cells) and implementing the autoimmune responses (through $\mathrm{CD}^{+} \mathrm{T}$ cells) in Type 1 diabetes, vitiligo and hypoparathyroidism.

\section{Acknowledgements}

We are thankful to the study participants: cases and the controls that provided blood samples for the study. Authors are thankful to Dr. Mitali Mukerji, IGIB, Delhi, for providing access to the Indian Genome Variation Consortium samples that have been used as unaffected controls in these studies. The projects were funded in part by grants from Department of Science and Technology (DST), Department of Biotechnology (DBT), Ministry of Science and Technology, Government of India and partly by Core funds of National Institute of Immunology, New Delhi, India. Diabetes work was supported by Department of Science \& Technology, New Delhi, India, grant No. SP/SO/B54/98. Vitiligo work was supported by grants for 'Genetic and autoimmune factors associated with vitiligo' (Grant number BT/PR6653/Med/12/258/2005) and the 'Program support for Skin pigmentation and melanocyte-keratinocyte biology' (grant number BT/01/COE/07/07) from the Department of Biotechnology, India. The hypoparathyroidism work was sponsored by Department of Biotechnology, grant number BT/ PR15022/Med/30/589/2010. The patient sample for this work came from All India Institute of Medical Sciences (AIIMS), New Delhi and Dr. Ram Manohar Lohia Hospital (RMLH), New Delhi, India. We would like to thank Dr. R. Goswami, Department of Endocrinology and Metabolism, (AIIMS) for T1D and hypoparathyroidism samples. We would like to acknowledge Dr. H. Kar (RMLH), Dr. V. K. Sharma (AIIMS) and Dr. Somesh Gupta (AIIMS), the dermatologists for providing the vitiligo samples. We thankfully acknowledge Dr. Rasheedunnisa Begum and her team for providing vitiligo samples for the replication study from Gujarat. We would like to acknowledge the students and project fellows who have been involved in doing this work. Mr. Kapoor Chand's technical support is acknowledged.

\section{Author details}

Rajni Rani and Archana Singh

Molecular Immunogenetics Group, National Institute of Immunology, New Delhi, India 


\section{References}

[1] Bowcock AM, Fernandez-Vina M Targeting skin: vitiligo and autoimmunity. J Invest Dermatol 2012; 132:13-15

[2] Horton R, Wilming L, Rand V, Lovering RC, Bruford EA, Khodiyar VK, Lush MJ, Povey S, Talbot CC, Jr., Wright MW, Wain HM, Trowsdale J, Ziegler A, Beck S Gene map of the extended human MHC. Nat Rev Genet 2004; 5:889-899

[3] Bjorkman PJ, Saper MA, Samraoui B, Bennett WS, Strominger JL, Wiley DC Structure of the human class I histocompatibility antigen, HLA-A2. Nature 1987; 329:506-512

[4] Falk K, Rotzschke O, Stevanovic S, Jung G, Rammensee HG Allele-specific motifs revealed by sequencing of self-peptides eluted from MHC molecules. Nature 1991; 351:290-296

[5] Garrett TP, Saper MA, Bjorkman PJ, Strominger JL, Wiley DC Specificity pockets for the side chains of peptide antigens in HLA-Aw68. Nature 1989; 342:692-696

[6] Sidney J, Peters B, Frahm N, Brander C, Sette A HLA class I supertypes: a revised and updated classification. BMC Immunol 2008; 9:1

[7] Holling TM, Schooten E, van Den Elsen PJ Function and regulation of MHC class II molecules in T-lymphocytes: of mice and men. Hum Immunol 2004; 65:282-290

[8] de Vries RR, van Rood JJ Immunobiology of HLA class-I and class-II molecules. Introduction. Prog Allergy 1985; 36:1-9

[9] Brown JH, Jardetzky TS, Gorga JC, Stern LJ, Urban RG, Strominger JL, Wiley DC Three-dimensional structure of the human class II histocompatibility antigen HLADR1. Nature 1993; 364:33-39

[10] Robinson J, Waller MJ, Fail SC, McWilliam H, Lopez R, Parham P, Marsh SG The IMGT/HLA database. Nucleic Acids Res 2009; 37:D1013-1017

[11] Robinson J, Mistry K, McWilliam H, Lopez R, Parham P, Marsh SG The IMGT/HLA database. Nucleic Acids Res 39:D1171-1176

[12] Kumar R, Goswami R, Agarwal S, Israni N, Singh SK, Rani R Association and interaction of the TNF-alpha gene with other pro- and anti-inflammatory cytokine genes and HLA genes in patients with type 1 diabetes from North India. Tissue Antigens 2007; 69:557-567

[13] Report of the expert committee on the diagnosis and classification of diabetes mellitus. Diabetes Care2003; 26 Suppl 1:S5-20

[14] Rani R, Sood A, Goswami R Molecular basis of predisposition to develop type 1 diabetes mellitus in North Indians. Tissue Antigens 2004; 64:145-155

[15] Singh A, Sharma P, Kar HK, Sharma VK, Tembhre MK, Gupta S, Laddha NC, Dwivedi M, Begum R, Gokhale RS, Rani R HLA Alleles and Amino-Acid Signatures of 
the Peptide-Binding Pockets of HLA Molecules in Vitiligo. J Invest Dermatol 2012; 132:124-134

[16] Goswami R, Singh A, Gupta N, Rani R Presence of Strong Association of the Major Histocompatibility Complex (MHC) Class I Allele HLA-A*26:01 with Idiopathic Hypoparathyroidism. J Clin Endocrinol Metab 06/2012; 97(9):E1820-4. DOI:10.1210/jc. 2012-1328

[17] Israni N, Goswami R, Kumar A, Rani R Interaction of vitamin D receptor with HLA DRB1 0301 in type 1 diabetes patients from North India. PLoS One 2009; 4:e8023

[18] Marsh SG, Albert ED, Bodmer WF, Bontrop RE, Dupont B, Erlich HA, Fernandez-Vina M, Geraghty DE, Holdsworth R, Hurley CK, Lau M, Lee KW, Mach B, Maiers M, Mayr WR, Muller CR, Parham P, Petersdorf EW, Sasazuki T, Strominger JL, Svejgaard A, Terasaki PI, Tiercy JM, Trowsdale J Nomenclature for factors of the HLA system, 2010. Tissue Antigens 2010; 75:291-455

[19] Woolf B On estimating the relation between blood group and disease. Ann Hum Genet 1955; 19:251-253

[20] Haldane JB The estimation and significance of the logarithm of a ratio of frequencies. Ann Hum Genet 1956; 20:309-311

[21] Rani R, Fernandez-Vina MA, Stastny P Associations between HLA class II alleles in a North Indian population. Tissue Antigens 1998; 52:37-43

[22] Pociot F, McDermott MF Genetics of type 1 diabetes mellitus. Genes Immun 2002; 3:235-249

[23] Todd JA Genetic analysis of type 1 diabetes using whole genome approaches. Proc Natl Acad Sci U S A 1995; 92:8560-8565

[24] Ramachandran A, Snehalatha C, Krishnaswamy CV Incidence of IDDM in children in urban population in southern India. Madras IDDM Registry Group Madras, South India. Diabetes Res Clin Pract 1996; 34:79-82

[25] Gupta MM, Raghunath D, Kher SK, Radhakrishnan AP Human leucocyte antigen and insulin dependent diabetes mellitus. J Assoc Physicians India 1991; 39:540-543

[26] Sanjeevi CB, Kanungo A, Shtauvere A, Samal KC, Tripathi BB Association of HLA class II alleles with different subgroups of diabetes mellitus in Eastern India identify different associations with IDDM and malnutrition-related diabetes. Tissue Antigens 1999; 54:83-87

[27] Mehra NK, Kaur G, Kanga U, Tandon N Immunogenetics of autoimmune diseases in Asian Indians. Ann N Y Acad Sci 2002; 958:333-336

[28] Witt CS, Price P, Kaur G, Cheong K, Kanga U, Sayer D, Christiansen F, Mehra NK Common HLA-B8-DR3 haplotype in Northern India is different from that found in Europe. Tissue Antigens 2002; 60:474-480 
[29] Kanga U, Vaidyanathan B, Jaini R, Menon PS, Mehra NK HLA haplotypes associated with type 1 diabetes mellitus in North Indian children. Hum Immunol 2004; 65:47-53

[30] Pugliese A, Gianani R, Moromisato R, Awdeh ZL, Alper CA, Erlich HA, Jackson RA, Eisenbarth GS HLA-DQB1*0602 is associated with dominant protection from diabetes even among islet cell antibody-positive first-degree relatives of patients with IDDM. Diabetes 1995; 44:608-613

[31] Baisch JM, Weeks T, Giles R, Hoover M, Stastny P, Capra JD Analysis of HLA-DQ genotypes and susceptibility in insulin-dependent diabetes mellitus. N Engl J Med 1990; 322:1836-1841

[32] Van der Auwera B, Van Waeyenberge C, Schuit F, Heimberg H, Vandewalle C, Gorus F, Flament J DRB1*0403 protects against IDDM in Caucasians with the high-risk heterozygous DQA1*0301-DQB1*0302/DQA1*0501-DQB1*0201 genotype. Belgian Diabetes Registry. Diabetes 1995; 44:527-530

[33] Ei Wafai RJ, Chmaisse HN, Makki RF, Fakhoury H Association of HLA class II alleles and CTLA-4 polymorphism with type 1 diabetes. Saudi J Kidney Dis Transpl 2011; 22:273-281

[34] Alves C, Toralles MB, Carvalho GC HLA class II polymorphism in patients with type 1 diabetes mellitus from a Brazilian racially admixtured population. Ethn Dis 2009; 19:420-424

[35] Weber P, Meluzinova H, Kubesova H, Ambrosova P, Polcarova V, Cejkova P, Cerna M Type 1 diabetes and LADA--occurrence of HLA-DRB1 *03 and DRB1 *04 alleles in two age different groups of diabetics. Adv Gerontol 2010; 23:243-248

[36] Skrodeniene E, Marciulionyte D, Padaiga Z, Jasinskiene E, Sadauskaite-Kuehne V, Sanjeevi CB, Ludvigsson J HLA class II alleles and haplotypes in Lithuanian children with type 1 diabetes and healthy children (HLA and type 1 diabetes). Medicina (Kaunas) $2010 ; 46: 505-510$

[37] Cucca F, Lampis R, Frau F, Macis D, Angius E, Masile P, Chessa M, Frongia P, Silvetti M, Cao A, De Virgiliis S, Congia M The distribution of DR4 haplotypes in Sardinia suggests a primary association of type I diabetes with DRB1 and DQB1 loci. Hum Immunol 1995; 43:301-308

[38] Garcia-Pacheco JM, Herbut B, Cutbush S, Hitman GA, Zhonglin W, Magzoub M, Bottazzo GF, Kiere C, West G, Mvere D, et al. Distribution of HLA-DQA1, -DQB1 and DRB1 alleles in black IDDM patients and controls from Zimbabwe. Tissue Antigens 1992; 40:145-149

[39] Fernandez-Vina M, Ramirez LC, Raskin P, Stastny P Genes for insulin-dependent diabetes mellitus (IDDM) in the major histocompatibility complex (MHC) of AfricanAmericans. Tissue Antigens 1993; 41:57-64 
[40] Tait BD, Drummond BP, Varney MD, Harrison LC HLA-DRB1*0401 is associated with susceptibility to insulin-dependent diabetes mellitus independently of the DQB1 locus. Eur J Immunogenet 1995; 22:289-297

[41] Sanjeevi CB, Landin-Olsson M, Kockum I, Dahlquist G, Lernmark A Effects of the second HLA-DQ haplotype on the association with childhood insulin-dependent diabetes mellitus. Tissue Antigens 1995; 45:148-152

[42] Taieb A, Picardo M The definition and assessment of vitiligo: a consensus report of the Vitiligo European Task Force. Pigment Cell Res 2007; 20:27-35

[43] Handa S, Kaur I Vitiligo: clinical findings in 1436 patients. J Dermatol 1999; 26:653-657

[44] Das SK, Majumder PP, Chakraborty R, Majumdar TK, Haldar B Studies on vitiligo. I. Epidemiological profile in Calcutta, India. Genet Epidemiol 1985; 2:71-78

[45] Shajil EM, Chatterjee S, Agrawal D, Bagchi T, Begum R Vitiligo: pathomechanisms and genetic polymorphism of susceptible genes. Indian J Exp Biol 2006; 44:526-539

[46] Kemp EH, Waterman EA, Weetman AP Immunological pathomechanisms in vitiligo. Expert Rev Mol Med 2001; 3:1-22

[47] Dell'anna ML, Picardo M A review and a new hypothesis for non-immunological pathogenetic mechanisms in vitiligo. Pigment Cell Res 2006; 19:406-411

[48] Lerner AB On the etiology of vitiligo and gray hair. Am J Med 1971; 51:141-147

[49] Bhatia PS, Mohan L, Pandey ON, Singh KK, Arora SK, Mukhija RD Genetic nature of vitiligo. J Dermatol Sci 1992; 4:180-184

[50] Kovacs SO Vitiligo. J Am Acad Dermatol 1998; 38:647-666; quiz 667-648

[51] Lang KS, Caroli CC, Muhm A, Wernet D, Moris A, Schittek B, Knauss-Scherwitz E, Stevanovic S, Rammensee HG, Garbe C HLA-A2 restricted, melanocyte-specific CD8(+) T lymphocytes detected in vitiligo patients are related to disease activity and are predominantly directed against MelanA/MART1. J Invest Dermatol 2001; 116:891-897

[52] Wankowicz-Kalinska A, van den Wijngaard RM, Tigges BJ, Westerhof W, Ogg GS, Cerundolo V, Storkus WJ, Das PK Immunopolarization of CD4+ and CD8+ T cells to Type-1-like is associated with melanocyte loss in human vitiligo. Lab Invest 2003; 83:683-695

[53] Waterman EA, Gawkrodger DJ, Watson PF, Weetman AP, Kemp EH Autoantigens in vitiligo identified by the serological selection of a phage-displayed melanocyte cDNA expression library. J Invest Dermatol 130:230-240 
[54] van den Boorn JG, Konijnenberg D, Dellemijn TA, van der Veen JP, Bos JD, Melief CJ, Vyth-Dreese FA, Luiten RM Autoimmune destruction of skin melanocytes by perilesional T cells from vitiligo patients. J Invest Dermatol 2009; 129:2220-2232

[55] Schwartz RA, Janniger CK Vitiligo. Cutis 1997; 60:239-244

[56] Majumder PP, Nordlund JJ, Nath SK Pattern of familial aggregation of vitiligo. Arch Dermatol 1993; 129:994-998

[57] Alkhateeb A, Fain PR, Thody A, Bennett DC, Spritz RA Epidemiology of vitiligo and associated autoimmune diseases in Caucasian probands and their families. Pigment Cell Res 2003; 16:208-214

[58] Quan C, Ren YQ, Xiang LH, Sun LD, Xu AE, Gao XH, Chen HD, Pu XM, Wu RN, Liang CZ, Li JB, Gao TW, Zhang JZ, Wang XL, Wang J, Yang RY, Liang L, Yu JB, Zuo XB, Zhang SQ, Zhang SM, Chen G, Zheng XD, Li P, Zhu J, Li YW, Wei XD, Hong WS, Ye Y, Zhang Y, Wu WS, Cheng H, Dong PL, Hu DY, Li Y, Li M, Zhang X, Tang HY, Tang XF, Xu SX, He SM, Lv YM, Shen M, Jiang HQ, Wang Y, Li K, Kang XJ, Liu YQ, Sun L, Liu ZF, Xie SQ, Zhu CY, Xu Q, Gao JP, Hu WL, Ni C, Pan TM, Yao S, He CF, Liu YS, Yu ZY, Yin XY, Zhang FY, Yang S, Zhou Y, Zhang XJ Genome-wide association study for vitiligo identifies susceptibility loci at 6q27 and the MHC. Nat Genet 2010; 42:614-618

[59] Jin Y, Birlea SA, Fain PR, Gowan K, Riccardi SL, Holland PJ, Mailloux CM, Sufit AJ, Hutton SM, Amadi-Myers A, Bennett DC, Wallace MR, McCormack WT, Kemp EH, Gawkrodger DJ, Weetman AP, Picardo M, Leone G, Taieb A, Jouary T, Ezzedine K, van Geel N, Lambert J, Overbeck A, Spritz RA Variant of TYR and autoimmunity susceptibility loci in generalized vitiligo. N Engl J Med 2010; 362:1686-1697

[60] Excoffier L, Laval G, Schneider S Arlequin (version 3.0): an integrated software package for population genetics data analysis. Evol Bioinform Online 2005; 1:47-50

[61] Excoffier L, Slatkin M Maximum-likelihood estimation of molecular haplotype frequencies in a diploid population. Mol Biol Evol 1995; 12:921-927

[62] Menconi F, Osman R, Monti MC, Greenberg DA, Concepcion ES, Tomer Y Shared molecular amino acid signature in the HLA-DR peptide binding pocket predisposes to both autoimmune diabetes and thyroiditis. Proc Natl Acad Sci U S A 2010; 107:16899-16903

[63] Rose NR Is idiopathic hypoparathyroidism an autoimmune disease? J Clin Invest 1996; 97:899-900

[64] Goswami R, Brown EM, Kochupillai N, Gupta N, Rani R, Kifor O, Chattopadhyay N Prevalence of calcium sensing receptor autoantibodies in patients with sporadic idiopathic hypoparathyroidism. Eur J Endocrinol 2004; 150:9-18 
[65] Goswami R, Goel S, Tomar N, Gupta N, Lumb V, Sharma YD Prevalence of clinical remission in patients with sporadic idiopathic hypoparathyroidism. Clin Endocrinol (Oxf) 2010; 72:328-333

[66] Goswami R, Marwaha RK, Goswami D, Gupta N, Ray D, Tomar N, Singh S Prevalence of thyroid autoimmunity in sporadic idiopathic hypoparathyroidism in comparison to type 1 diabetes and premature ovarian failure. J Clin Endocrinol Metab 2006; 91:4256-4259

[67] Goswami R, Bhatia M, Goyal R, Kochupillai N Reversible peripheral neuropathy in idiopathic hypoparathyroidism. Acta Neurol Scand 2002; 105:128-131

[68] Goswami R, Mohapatra T, Gupta N, Rani R, Tomar N, Dikshit A, Sharma RK Parathyroid hormone gene polymorphism and sporadic idiopathic hypoparathyroidism. J Clin Endocrinol Metab 2004; 89:4840-4845

[69] Goswami R, Gupta N, Ray D, Rani R, Tomar N, Sarin R, Vupputuri MR Polymorphisms at $+49 \mathrm{~A} / \mathrm{G}$ and CT60 sites in the 3' UTR of the CTLA-4 gene and APECEDrelated AIRE gene mutations analysis in sporadic idiopathic hypoparathyroidism. Int J Immunogenet 2005; 32:393-400

[70] Sarin R, Tomar N, Ray D, Gupta N, Sharma YD, Goswami R Absence of pathogenic calcium sensing receptor mutations in sporadic idiopathic hypoparathyroidism. Clin Endocrinol (Oxf) 2006; 65:359-363

[71] Todd JA, Bell JI, McDevitt HO HLA-DQ beta gene contributes to susceptibility and resistance to insulin-dependent diabetes mellitus. Nature 1987; 329:599-604

[72] Winchester R The molecular basis of susceptibility to rheumatoid arthritis. Adv Immunol 1994; 56:389-466 
